\title{
Effects of Interdisciplinery Nutrition Education on Prospective Science Teachers' Development of Healthy Life Style Behaviours
}

\author{
Hatice Mertoglu \\ Correspondence: Hatice Mertoglu, Assoc. Prof. Dr., Marmara University, İstanbul, Turkey. \\ Received: October 23, 2019 \\ doi:10.11114/jets.v7i12.4578 \\ Accepted: November 25, $2019 \quad$ Online Published: November 27, 2019 \\ URL: https://doi.org/10.11114/jets.v7i12.4578
}

\begin{abstract}
With the interdisciplinary approach which is developed as an alternative to the traditional disciplinary model in education, it is aimed that the students will have a holistic perspective while producing solutions to real life problems. In this study, the effects of nutrition education given with interdisciplinary approach on health development behaviors of prospective teachers were investigated. The research has an experimental research model, which is one of the quantitative research designs. The sample of the study is consisting of 60 prospective teachers studying in the science teaching department of a state university in Istanbul in the 2016-2017 education year. In this study, in addition to demographic information form that has been applied, the Healthy Life Style Behavior Scale II (HLSBS-II) was also applied to the experimental and control group students in order to determine healthy life style behaviors of students. SPSS 23 package program was used to perform statistical analysis of the gathered data. When the post-test data were analyzed, it was seen that there were significant differences between four sub-dimensions (physical activity, nutrition, inner development and stress management) and overall scores of the two groups $(\mathrm{p}<.05)$. When the research results are examined, it appears that interdisciplinary nutrition education has a positive effect on students' healthy life style behaviors. The information obtained in the research was discussed and recommendations were made accordingly.
\end{abstract}

Keywords: healthy life style behaviors, interdisciplinary approach, nutrition education, prospective science teachers

\section{Introduction}

Health has always been an important position for the welfare and continuity of society. Whereas health care is organized within this importance, it has undergone many changes and has taken shape to meet the needs of people and societies. While health care models have aimed to improve health in the past, nowadays these models are more interested in protecting from diseases and improving health (Carreno, Vyhmeister, Grau \& Ivanovic, 2006). The World Health Organization (1995) defined the concept of health as a state of complete well-being in terms of physical, mental and social aspects, not merely the absence of disease or infirmity. The individual must have a healthy life style to preserve, maintain and improve the well-being described in this definition.

Since the emergence of civilizations, four different ages have been experienced, and all of these ages had different characteristics, sociological structures and economies. In these days of the information age, with the industrialization and modernization, life styles of today's people has changed considerably compared to the past, people and nature have moved away from each other and the rate of urbanization has reached the highest level (Al Ma'aitah, Haddad \& Umlauf, 1999; Kocatepe \& Trril, 2015). In this modern structure of life, which altered many orders in daily life, the work lives, occupations and daily activities of individuals have also changed. Modernism, which breaks the social structure and routines from the conventional, has also changed the nutrition culture, way of life, the ingredients of foods and the manufacturing types (Al Ma'aitah, Haddad \& Umlauf, 1999). This considerable change in people's life styles has caused some negative effects on their health. Alterations in the health behaviors of individuals have occurred with the changing daily life.

In the literature, health behaviors are divided into two groups as health-promoting behaviors and health-damaging behaviors. Health-damaging behaviors, such as smoking, excessive alcohol consumption, consuming excess fatty foods, etc., increase the vulnerability and sensitivity of the individual against negative health consequences (Engle, Castle \& Menon, 1996; Ak, Çelen, Özen, Tabak \& Piyal, 2006). Lack of physical activity is also included in these behaviors. The changing life styles of people in the $21^{\text {st }}$ century increased the prevalence of these health-damaging behaviors.

The University education is a period in which students begin to gain decision-making skills with coming of age. Pre-adult 
individuals, who graduated from high school and started university, may exhibit behavioral changes due to alterations in their life styles. They become more vulnerable to external influences as they depart from their accustomed family environments and may develop negative behaviors in terms of health. According to Arslan and Pekcan (1985)'s research, students prefer ready-to-eat products such as toast and sandwiches which are easily accessible and cheap for lunch and dinner. In another study conducted, it was revealed that the students generally disrupted the lunch and asserted the inadequacy of their time as the reason for this situation (Sinir, İnceday1, Çopur, Kaplan \& Bekaroğlu, 2014). On the other hand, another problem related to health is the lack of physical activity. According to a study conducted in the United States, there is a dramatic decline in the rates of participation in community recreation programs and fitness activities. It has also been shown that students spend more time watching television than when they spend on physical activity (Heath, Pratt, Warren \& Kann, 1994).

Individuals with a healthy life style exhibit some behaviors that they turned into an attitude in order to maintain and improve their current health status. Individuals who internalize these behaviors, which are called healthy life style behaviors, perform some actions, such as exercising, adequate and balanced nourishment, etc., that protects the health of them and keep them away from diseases (Ak et al., 2006). Individuals should have the ability to use self-control mechanisms to develop these behaviors (Özyazıcıoğlu, Kılıç, Erdem, Yavuz \& Afacan, 2011).

The behavioral development process can be possible by providing the individuals with sufficient knowledge and skills. Therefore, the importance of education in developing healthy life style behaviors cannot be ignored. Individuals acquire these behaviors firstly through society and family. However, due to different social and family structures, differences or deficiencies in healthy life style behaviors of individuals may occur. The education system undertakes the function of overcoming these deficiencies and modifying possible misconceptions. In this context, schools can be considered as suitable environments for developing healthy life style behaviors (Tokuç \& Berberoğlu, 2007).

In disciplinary teaching approach, concepts and subjects are examined only within the framework of certain discipline which is accepted as related with the concept or the subject. The knowledge and skills gained through this approach may be insufficient to produce solutions to daily life problems. The main reason is the differentiated way of thinking that the disciplinary approach brings to the human being who tends to perceive the outside world as a whole (Yildirım, 1996). The vast majority of students experience difficulty in associating the knowledge they have learned in school with real-world experiences (Jacobs, 1989). Teachers are constantly exposed to the questions from their students about the necessity of the subjects covered. When the relations of the concepts and subjects with different disciplines are ignored and they examined within a framework of single discipline, problems may arise in the process of applying the knowledge learned in theory to the practice. For this reason, it is obligatory to address the subjects, which are of interest to various disciplines, with an interdisciplinary approach. Jacobs $(1989$, p.8) defined the interdisciplinary approach as "A knowledge view and curriculum approach that consciously applies methodology and language from more than one discipline to examine a central theme, issue, problem, topic, or experience". As can be seen from this definition, the interdisciplinary teaching model provides students with the opportunity to approach the subjects and concepts in a holistic way and, by turning away from the view of traditional knowledge, gain the ability to examine from different perspectives that will serve them in the real world. In this way, students would have the opportunity to observe the practical applications of the learned knowledge by adopting the skills of flexible thinking and developing multiple perspectives. Taking all these into consideration, it can be concluded that, in addition to the traditional disciplinary approach in education, an interdisciplinary approach to the study of the subjects of different disciplines would contribute to the development of students (Jacobs, 1989).

Since, the concept of nutrition has an interdisciplinary nature, nutrition education should be handled with an interdisciplinary approach. The interdisciplinary approach is implemented by integrating the approaches, methods, knowledge and skills specific to various disciplines in a complementary manner (Yıldırım, 1996). These subjects and concepts are examined by referring to the opinions of experts from the disciplines throughout the educational process (Baumslag, Gatins, Watson \& Englund, 1976). In the educational process, with the inclusion of experts from different disciplines students would have the opportunity to observe the daily life practices of the knowledge they have learned in theory, and in this way the goal of acquiring healthy eating habits, which is the main objective of nutrition education, would be achieved. Taking into account all of these, the need for addressing nutrition education with an interdisciplinary approach is once again emphasized.

In this study, it is aimed to investigate the effects of nutrition education introduced with interdisciplinary approach on the healthy life style behaviors of pre-service science teachers.

\section{Method}

This study was an experimental research conducted to investigate the effects of interdisciplinary nutrition education course on health promoting behaviors of pre-service science teachers. The research design of the study was determined as the pretest - posttest quasi-experimental model with control group. For quasi-experimental researches, sample is selected 
by purposive sampling method (Büyüköztürk, Kılıç Çakmak, Akgün, Karadeniz \& Demirel, 2013; Sönmez \& Alacapınar, 2016).

\subsection{Sample}

The sample of the study was consisting of 60 pre-service science teachers who are senior students in a state university in Istanbul. All of the pre-service science teachers stated that they did not receive any kind of course or training on nutrition-health. In addition, the teacher candidates who formed the experimental group stated that they chose the nutrition-health education course, which is an elective course, voluntarily and they wanted to be educated on this subject. Detailed information on the sample is shown in Table 1 below.

Table 1. Some demographic and health-related characteristics of pre-service teachers

\begin{tabular}{|c|c|c|c|c|c|c|c|}
\hline \multirow[t]{2}{*}{ Variable } & \multirow[t]{2}{*}{ Group } & \multicolumn{2}{|c|}{$\begin{array}{c}\text { Experimental G. } \\
(\mathrm{N}=20)\end{array}$} & \multicolumn{2}{|c|}{$\begin{array}{l}\text { Control G. } \\
(\mathrm{N}=40)\end{array}$} & \multicolumn{2}{|c|}{$\underset{(N=60)}{\text { Sum }}$} \\
\hline & & $\mathrm{N}$ & $\%$ & $\mathrm{~N}$ & $\%$ & $\mathrm{~N}$ & $\%$ \\
\hline \multirow[t]{2}{*}{ Gender } & Female & 19 & 95.0 & 36 & 90.0 & 55 & 91.7 \\
\hline & Male & 1 & 5.0 & 4 & 10.0 & 5 & 8.3 \\
\hline \multirow[t]{5}{*}{ Settlement Type } & State dorm & 1 & 5.0 & 3 & 7.5 & 4 & 6.7 \\
\hline & Private dorm & 1 & 5.0 & 4 & 10.0 & 5 & 8.3 \\
\hline & Live with friends & 4 & 20.0 & 2 & 5.0 & 6 & 10 \\
\hline & Live by oneself & 0 & 0.0 & 1 & 2.5 & 1 & 1.7 \\
\hline & Live with parents & 14 & 70.0 & 30 & 75.0 & 44 & 73.3 \\
\hline \multirow[t]{4}{*}{ Economic condition } & Very good & 1 & 5.0 & 0 & 0.0 & 1 & 1.7 \\
\hline & Good & 10 & 50.0 & 14 & 35.0 & 24 & 40 \\
\hline & Moderate & 8 & 40.0 & 23 & 57.5 & 31 & 51.7 \\
\hline & Bad & 1 & 5.0 & 3 & 7.5 & 4 & 6.7 \\
\hline \multirow{5}{*}{$\begin{array}{l}\text { Mother's educational } \\
\text { status }\end{array}$} & Literate/illiterate & 2 & 10.0 & 0 & 0.0 & 2 & 3.3 \\
\hline & Primary school graduate & 9 & 45.0 & 19 & 47.5 & 28 & 46.7 \\
\hline & Secondary school graduate & 2 & 10.0 & 8 & 20.0 & 10 & 16.7 \\
\hline & High school graduate & 5 & 25.0 & 8 & 20.0 & 13 & 21.7 \\
\hline & College graduate & 2 & 10.0 & 5 & 12.5 & 7 & 11.7 \\
\hline \multirow[t]{4}{*}{ Self-rated health } & Very good & 6 & 30.0 & 10 & 25.0 & 16 & 26.7 \\
\hline & Good & 9 & 45.0 & 28 & 70.0 & 37 & 61.7 \\
\hline & Moderate & 3 & 15.0 & 2 & 5.0 & 5 & 8.3 \\
\hline & $\mathrm{Bad}$ & 2 & 10.0 & 0 & 0.0 & 2 & 3.3 \\
\hline \multirow[t]{3}{*}{ Smoking habit } & Nonsmoker & 20 & 100.0 & 34 & 85.0 & 54 & 90 \\
\hline & Daily & 0 & 0.0 & 3 & 7.5 & 3 & 5 \\
\hline & Occasionally & 0 & 0.0 & 3 & 7.5 & 3 & 5 \\
\hline \multirow[t]{2}{*}{ Chronic illness } & Yes & 3 & 15.0 & 4 & 10.0 & 7 & 11.7 \\
\hline & No & 17 & 85.0 & 36 & 90.0 & 53 & 88.3 \\
\hline \multirow{2}{*}{$\begin{array}{l}\text { Thinking of having } \\
\text { healthy lifestyle }\end{array}$} & Yes & 15 & 75.0 & 17 & 42.5 & 32 & 53.3 \\
\hline & No & 5 & 25.0 & 23 & 57.5 & 28 & 46.7 \\
\hline \multirow{2}{*}{$\begin{array}{l}\text { Thinking of having } \\
\text { healthy diet }\end{array}$} & Yes & 13 & 65.0 & 13 & 32.5 & 26 & 43.3 \\
\hline & No & 7 & 35.0 & 27 & 67.5 & 34 & 56.7 \\
\hline
\end{tabular}

$91.7 \%$ of the teacher candidates participating in the study were female and $8.3 \%$ of them were male, and a large proportion of participants (73.3\%) are living with their family. $51.7 \%$ of the pre-service teachers state that their families' economic status at a moderate level and $46.7 \%$ of participants' mothers are primary school graduates. $61.7 \%$ of the pre-service teachers considered their health as good and $90.0 \%$ of them are nonsmoker. $88.3 \%$ of the pre-service teachers do not have a chronic disease, $53.3 \%$ of them think that they live healthy and $43.3 \%$ of them think that they have healthy diet.

\subsection{Data Collection Tools}

In this study, data were collected through "Personal Information Form" and "the Healthy Life Style Behavior Scale II (HLSBS-II)".

\section{Personal Information Form}

"Personal Information Form" developed by the researcher was used to determine some demographic and health-related characteristics of the pre-service science teachers.

Healthy Life Style Behavior Scale II (HLSBS-II)

In order to measure the perceptions of the participant pre-service science teachers about health promoting behaviors, the 
Healthy Life Style Behavior Scale II (HLSBS-II) which was developed by Walker, Sechrist and Pender (1987) and translated into Turkish by Bahar, Beşer, Gördes, Ersin and Kıssal (2008) was used. The scale has 52 items and six health promoting behavior subscales: health responsibility; physical activity; nutritional habits; spiritual growth; interpersonal relations; and stress management. Health responsibility subscale determines person's level of responsibility for his/her own health, which contributes to his/her health. Physical activity includes adhering to regular exercise patterns. Nutritional habits subscale determines the person's choice of nutrients and their attitude in selecting and arranging their meals. Spiritual growth subscale determines the person's life goals, his/her ability to develop himself/herself, how much he/she knows himself/herself and his/her satisfaction. Interpersonal relations subscale determines the level and continuity of communication with the person's immediate circle. Stress management subscale determines the level of recognition of the situations that cause stress and the ability to control stress.

The internal consistency coefficient (Alpha coefficient) of the scale was calculated as $\alpha=.92$ and for the subscales as $\alpha=.64-.79$ by the developers of the scale. The items of the 4-point Likert-type scale are evaluated between ' 1 ' (Very uncharacteristic of me) and ' 4 ' (Very characteristic of me) and the scale has no reverse-coded items. As the total score obtained from the scale increases, it is indicated that the individual has a self-perception of having a healthy life style, while the low score from the scale shows that he/she has a self-perception that states for unhealthy life style. The range of scores that can be taken from the scale varies between 52 and 208. However, because of the different number of items in the subscales, average scores were used instead of the total score in order to make the comparisons more practical in this study.

The researchers examined the suitability of the Healthy Life Style Behavior Scale II (HLSBS-II) for this study by examining reliability by the item analysis. Alpha model was used for the internal consistency reliability of the scale (Kalayc1, 2006, p. 405). As a result of the reliability analysis conducted for the HLSBS-II scale, the overall reliability coefficient (Cronbach's Alpha) was calculated as $\alpha=.92$ for this study. The reliability coefficients of the subscales vary between $\alpha=.60$ and $\alpha=.88$. This result shows that the HLSBS-II scale is reliable for this study.

\subsection{Implementation}

Personal Information Form and the Healthy Life Style Behavior Scale II (HLSBS-II) were conducted as pre-test to the participant pre-service teachers. Then the experimental group was formed with 20 pre-service teachers who voluntarily selected the nutrition education course as selective. It is checked whether the experimental and control groups were equivalent by the HLSBS-II scale pre-test scores. After the two groups were found to be equivalent, nutrition education course was taught through an interdisciplinary approach.

\section{Interdisciplinary Nutrition Education}

In the process of developing education program with interdisciplinary approach, sub-topics and concepts from different disciplines are determined (Yıldırım, 1996). These topics and concepts are examined by applying to the opinions of the experts from these disciplines. Examples of sub-topics from different disciplines in nutrition education are; nutrient types, calorie calculations, vitamins and minerals, diets for different groups, genetically modified organisms (GMOs), organic products and so on (Baumslag et al., 1976). In this context, firstly the topics and concepts related to nutrition education were determined: 'Carbohydrate and its importance', 'protein and its importance', 'fats, trans fatty, cholesterol, labels, additives and their effects', 'vitamins, GMO, organic, hormonal foods', 'minerals, water, antioxidants, supplements', 'adequate and balanced nutrition, obesity, anorexia, malnutrition, body mass index, food groups, calorie calculations and daily amounts to be taken', 'diet plans for primary school children, nutrition and health problems'. Then the students were divided into groups and the topics were shared. Each group was asked to perform semi-structured interviews with 2 different experts from different disciplines. Thus, "Interdisciplinary Expert Meetings" were fulfilled.

\section{Interdisciplinary Expert Meetings}

While developing an interdisciplinary nutrition program, it is necessary to ensure that people from different subject areas participate in the process as far as possible (Yıldırım, 1996). As the concepts related to the nutrition-health be directly associated with many different disciplines, the topics in the content of the nutrition health education course, designated for group studies were examined not only in terms of educational aspects but also in many fields of health, such as medicine, pharmacy, dietetics in a multi-faceted way. The pre-service science teachers had interviews with experts from different fields such as medical doctor, dietician, pharmacist, water analysts (laborant), sports center employees, and organic farmers about their topics. For example, while interviewing with doctors, diseases related to the nutrition-health topic were mentioned, also dietician make some suggestions about healthy nourishment during the interview. During the interviews with doctors, pharmacists and sports instructors at the sports center have highlighted promoters such as vitamins, minerals and different perspectives on the use of protein powders. During the meeting with organic market sellers, organic product cultivation process was discussed. After the interviewing process, the pre-service teachers shared their works and interview reports with their friends and a platform was created in the classroom. At the end of the implementation, the Healthy Life Style Behavior Scale II (HLSBS-II) was re-applied to both groups. 


\subsection{Analysis of Research Data}

In order to summarize the demographic characteristics of pre-service teachers, the frequency (n) and percentage distributions (\%) values and to summarize the HLSBS-II scale pre-test and post-test scores, mean and standard deviation values were calculated. Since the HLSBS-II scale scores of the groups did not show normality distribution (p <.05), non-parametric tests were used to compare the scores of the experimental and control groups, and to compare the pre-test and post-test scores of the experimental group.

\section{Results}

In this section; the analysis of effectiveness of the nutrition education course introduced by the interdisciplinary approach on the health promoting behaviors of the pre-service teachers are included. The HLSBS-II scale scores of the teacher candidates in the experimental and control groups, before the interdisciplinary nutrition education course was introduced, were given in Table 2.

Table 2. Descriptive statistics of the HLSBS-II scale pretest scores of the pre-service teachers in the experimental and control groups

\begin{tabular}{lccccc}
\hline \multirow{2}{*}{ Subscale } & \multicolumn{2}{c}{ Experimental group } & & \multicolumn{2}{c}{ Control Group } \\
\cline { 2 - 3 } \cline { 6 - 7 } & $\mathrm{M}$ & $\mathrm{SD}$ & & $\mathrm{M}$ & $\mathrm{SD}$ \\
\hline Health responsibility & 2.17 & 0.64 & & 2.47 & 0.56 \\
Physical activity & 2.13 & 0.75 & & 2.04 & 0.68 \\
Nutritional habits & 2.51 & 0.53 & & 2.33 & 0.40 \\
Spiritual growth & 3.23 & 0.38 & & 3.12 & 0.49 \\
Interpersonal relations & 3.00 & 0.59 & & 3.09 & 0.48 \\
Stress management & 2.60 & 0.44 & & 2.53 & 0.44 \\
\hline Total HLSBS-II & 2.61 & 0.44 & & 2.60 & 0.36
\end{tabular}

According to Table 2; the lowest mean score of the teacher candidates in the experimental group for subscales was found to be $\mathrm{M}=2.13(\mathrm{SD}=.75)$ for physical activity subscale and the highest mean score was $\mathrm{M}=3.23(\mathrm{SD}=.38)$ for spiritual growth subscale. The overall mean score of the teacher candidates in the experimental group was calculated as $\mathrm{M}=2.61$ $(\mathrm{SD}=.44)$ (on a "regularly" level).

The lowest mean score of the pre-service teachers in the control group was $\mathrm{M}=2.04(\mathrm{SD}=.68)$ for physical activity subscale and the highest mean score was found to be $\mathrm{M}=3.12(\mathrm{SD}=.49)$ for spiritual growth subscale. The overall mean score of the control group was calculated as $\mathrm{M}=2.60(\mathrm{SD}=.36)$ (on a "regularly" level).

The equivalence of the experimental and control groups was tested by comparing pre-test scores of the HLSBS-II scale and the results are summarized in Table 3 below. 
Table 3. The Mann-Whitney test for the comparison of pre-test scores of the HLSBS-II scale of the pre-service teachers in the experimental and control groups $(\mathrm{N}=60)$

\begin{tabular}{|c|c|c|c|c|c|c|}
\hline \multirow[b]{2}{*}{ Subscale } & \multirow[b]{2}{*}{ Group } & \multicolumn{3}{|c|}{ Descriptive Stats. } & \multicolumn{2}{|c|}{ Mann-Whitney } \\
\hline & & $\mathrm{N}$ & $\begin{array}{l}\text { Mean } \\
\text { Rank }\end{array}$ & $\begin{array}{l}\text { Sum of } \\
\text { Ranks }\end{array}$ & $\mathrm{Z}$ & $\mathrm{p}$ \\
\hline \multirow[t]{2}{*}{ Health responsibility } & Experimental & 20 & 33.30 & 466.00 & -1.67 & 0.083 \\
\hline & Control & 40 & 34.10 & 1364.00 & & \\
\hline \multirow[t]{2}{*}{ Physical activity } & Experimental & 20 & 32.13 & 642.50 & -0.51 & 0.609 \\
\hline & Control & 40 & 29.69 & 1187.50 & & \\
\hline \multirow[t]{2}{*}{ Nutritional habits } & Experimental & 20 & 34.33 & 686.50 & -1.21 & 0.227 \\
\hline & Control & 40 & 28.59 & 1143.50 & & \\
\hline \multirow[t]{2}{*}{ Spiritual growth } & Experimental & 20 & 33.48 & 669.50 & -0.94 & 0.349 \\
\hline & Control & 40 & 29.01 & 1160.50 & & \\
\hline \multirow{2}{*}{$\begin{array}{l}\text { Interpersonal } \\
\text { relations }\end{array}$} & Experimental & 20 & 28.85 & 577.00 & -0.52 & 0.604 \\
\hline & Control & 40 & 31.33 & 1253.00 & & \\
\hline \multirow[t]{2}{*}{ Stress management } & Experimental & 20 & 32.85 & 657.00 & -0.74 & 0.459 \\
\hline & Control & 40 & 29.33 & 1173.00 & & \\
\hline \multirow[t]{2}{*}{ Total HLSBS-II } & Experimental & 20 & 30.85 & 617.00 & -0.11 & 0.913 \\
\hline & Control & 40 & 30.33 & 1213.00 & & \\
\hline
\end{tabular}

The non-parametric Mann-Whitney test was used to determine whether there was a significant difference according to the pre-test scores of the teacher candidates in the experimental and control groups and the results are given in Table 3 above. The mean rank scores of the subscales of the test were quite similar to each other as seen in the descriptive statistics section of Table 3. There is no significant difference between the scores of the teacher candidates in the control and experimental groups for both the subscales and overall scale. This result indicates that the experimental and control groups are equivalent groups according to the HLSBS-II scale scores before the interdisciplinary nutrition education course was introduced.

After the interdisciplinary nutrition education course was introduced to the experimental group, the HLSBS-II scale was re-applied to the experimental and control groups and the results are summarized in Table 4 below. 
Table 4. The Mann-Whitney test for the comparison of the post-test scores of the HLSBS-II scale of pre-service teachers in the experimental and control groups $(\mathrm{N}=60)$

\begin{tabular}{|c|c|c|c|c|c|c|}
\hline \multirow{2}{*}{ Subscale } & \multirow{2}{*}{ Group } & \multicolumn{3}{|c|}{ Descriptive Stats. } & \multicolumn{2}{|c|}{ Mann-Whitney } \\
\hline & & $\mathrm{N}$ & $\begin{array}{l}\text { Mean } \\
\text { Rank }\end{array}$ & $\begin{array}{l}\text { Sum of } \\
\text { Ranks }\end{array}$ & $\mathrm{Z}$ & $\mathrm{p}$ \\
\hline \multirow{2}{*}{$\begin{array}{l}\text { Health } \\
\text { responsibility }\end{array}$} & Experimental & 20 & 31.25 & 625.00 & -0.24 & 0.814 \\
\hline & Control & 40 & 30.13 & 1205.00 & & \\
\hline \multirow[t]{2}{*}{ Physical activity } & Experimental & 20 & 35.93 & 718.50 & -2.16 & $0.038^{*}$ \\
\hline & Control & 40 & 27.79 & 1111.50 & & \\
\hline \multirow[t]{2}{*}{ Nutritional habits } & Experimental & 20 & 35.58 & 711.50 & -2.10 & $0.041 *$ \\
\hline & Control & 40 & 27.96 & 1118.50 & & \\
\hline \multirow[t]{2}{*}{ Spiritual growth } & Experimental & 20 & 35.23 & 704.50 & -2.06 & $0.047 *$ \\
\hline & Control & 40 & 28.14 & 1125.50 & & \\
\hline \multirow{2}{*}{$\begin{array}{l}\text { Interpersonal } \\
\text { relations }\end{array}$} & Experimental & 20 & 31.45 & 629.00 & -0.30 & 0.765 \\
\hline & Control & 40 & 30.03 & 1201.00 & & \\
\hline \multirow[t]{2}{*}{ Stress management } & Experimental & 20 & 36.13 & 722.50 & -2.29 & $0.027 *$ \\
\hline & Control & 40 & 27.69 & 1107.50 & & \\
\hline \multirow[t]{2}{*}{ Total HLSBS-II } & Experimental & 20 & 35.75 & 715.00 & -2.14 & $0.040 *$ \\
\hline & Control & 40 & 27.88 & 1115.00 & & \\
\hline
\end{tabular}

As it can be seen from Table 4, after the interdisciplinary nutrition education course was introduced to the experimental group, the HLSBS-II scale was re-applied to the experimental and control groups as post-test and it was seen that there was a significant difference between groups in terms of the four subscales and overall scores of the scale. According to this;

- There is no significant difference between the levels of health responsibility behavior of the teacher candidates in the experimental and control groups $[\mathrm{Z}=-0.24 ; \mathrm{p}>.05]$. The pre-service teachers in the experimental and control groups had similar health responsibility behavior levels.

- There is a significant difference between the physical activity levels of the teacher candidates in the experimental and control groups $[\mathrm{Z}=-2.16 ; \mathrm{p}<.05]$. The physical activity level of the pre-service teachers in the experimental group (Mean Rank Experimental Group = 35.93) was higher than the pre-service teachers in the control group (Mean Rank Control Group = 27.79).

- There is a significant difference between the levels of nutritional habits of the teacher candidates in the experimental and control groups $[\mathrm{Z}=-2.10 ; \mathrm{p}<.05]$. Nutritional habits levels of the pre-service teachers in the experimental group (Mean Rank Experimental Group $=35.58$ ) were higher than the teacher candidates in the control group (Mean Rank Control Group = 27.96).

- There is a significant difference between the levels of the spiritual growth of the teacher candidates in the experimental and control groups $[\mathrm{Z}=-2.06 ; \mathrm{p}<.05]$. The level of spiritual growth of the pre-service teachers in the experimental group (Mean Rank Experimental Group $=35.23$ ) is higher than the teacher candidates in the control group (Mean Rank Control Group = 28.14). 
- There is no significant difference between the levels of interpersonal relations behavior of the teacher candidates in the experimental and control groups $[\mathrm{Z}=-0.30 ; \mathrm{p}>.05]$. The pre-service teachers in the experimental and control groups had similar levels of interpersonal relations behavior.

- There is a significant difference between the levels of stress management of the teacher candidates in the experimental and control groups $[\mathrm{Z}=-2.29 ; \mathrm{p}<.05]$. The stress management levels of the pre-service teachers in the experimental group (Mean Rank Experimental Group $=36.13$ ) were higher than the pre-service teachers in the control group (Mean Rank Control Group =27.69).

- Finally, it was found that there is a significant difference between the levels of general health promoting behaviors of the pre-service teachers in the experimental and control groups $[\mathrm{Z}=-2.14 ; \mathrm{p}<.05]$. The healthy life style behavior levels of the pre-service teachers in the experimental group (Mean Rank Experimental Group = 35.75) were higher than the pre-service teachers in the control group (Mean Rank Control Group $=27.88$ ).

Table 5. Descriptive statistics of pre-test and post-test scores of pre-service teachers in the experimental group

\begin{tabular}{|c|c|c|c|c|c|}
\hline \multirow{2}{*}{ Subscale } & \multicolumn{2}{|c|}{ Pre-Test } & \multicolumn{2}{|c|}{ Post-Test } & \multirow{2}{*}{$\begin{array}{c}\text { Mean } \\
\text { Difference }\end{array}$} \\
\hline & M & SD & M & SD & \\
\hline Health responsibility & 2.17 & 0.64 & 2.62 & 0.62 & 0.45 \\
\hline Physical activity & 2.13 & 0.75 & 2.48 & 0.84 & 0.35 \\
\hline Nutritional habits & 2.51 & 0.53 & 2.79 & 0.59 & 0.28 \\
\hline Spiritual growth & 3.23 & 0.38 & 3.56 & 0.41 & 0.33 \\
\hline Interpersonal relations & 3.00 & 0.59 & 3.15 & 0.60 & 0.15 \\
\hline Stress management & 2.60 & 0.44 & 2.80 & 0.46 & 0.20 \\
\hline Total HLSBS-II & 2.61 & 0.44 & 2.84 & 0.46 & 0.23 \\
\hline
\end{tabular}

The HLSBS-II scale mean scores calculated before and after the interdisciplinary nutrition education course are given in Table 5 above. According to this; it is seen that pre-test scores of teacher candidates in the experimental group about all subscales and overall scale increased. When the mean differences between the pre-test and post-test scores are examined, it is understood that the highest mean difference is 0.45 for health responsibility subscale and the lowest mean difference is 0.15 for interpersonal relations subscale. The significance of these differences between pre-test and post-test scores of pre-service teachers in the experimental group was examined by Wilcoxon Signed Rank Test and the results are summarized in Table 6 below. 
Table 6. Wilcoxon test results for the comparison of pre-test and post-test scores of pre-service teachers in the experimental group

\begin{tabular}{|c|c|c|c|c|c|c|}
\hline \multirow[b]{2}{*}{ Subscale } & \multirow[b]{2}{*}{ Ranks } & \multicolumn{3}{|c|}{ Descriptive Stats. } & \multicolumn{2}{|c|}{ Wilcoxon Test } \\
\hline & & $\mathrm{N}$ & $\begin{array}{l}\text { Mean } \\
\text { Rank }\end{array}$ & $\begin{array}{l}\text { Sum of } \\
\text { Ranks }\end{array}$ & $\mathrm{Z}$ & $\mathrm{p}$ \\
\hline \multirow{3}{*}{$\begin{array}{l}\text { Health } \\
\text { responsibility }\end{array}$} & Negative Ranks & 1 & 9.81 & 13.50 & -3.29 & $0.001 * *$ \\
\hline & Positive Ranks & 18 & 13.50 & 176.50 & & \\
\hline & Ties & 1 & & & & \\
\hline \multirow{3}{*}{$\begin{array}{l}\text { Physical } \\
\text { activity }\end{array}$} & Negative Ranks & 2 & 5.25 & 10.50 & -2.82 & $0.005^{* *}$ \\
\hline & Positive Ranks & 13 & 8.42 & 109.50 & & \\
\hline & Ties & 5 & & & & \\
\hline \multirow{3}{*}{$\begin{array}{l}\text { Nutritional } \\
\text { habits }\end{array}$} & Negative Ranks & 5 & 9.80 & 49.00 & -2.31 & $0.021^{*}$ \\
\hline & Positive Ranks & 12 & 13.67 & 104.00 & & \\
\hline & Ties & 3 & & & & \\
\hline \multirow{3}{*}{$\begin{array}{l}\text { Spiritual } \\
\text { growth }\end{array}$} & Negative Ranks & 6 & 8.33 & 50.00 & -2.03 & $0.048^{*}$ \\
\hline & Positive Ranks & 13 & 10.77 & 140.00 & & \\
\hline & Ties & 1 & & & & \\
\hline \multirow{3}{*}{$\begin{array}{l}\text { Interpersonal } \\
\text { relations }\end{array}$} & Negative Ranks & 4 & 14.13 & 56.50 & -1.27 & 0.204 \\
\hline & Positive Ranks & 14 & 8.18 & 114.50 & & \\
\hline & Ties & 2 & & & & \\
\hline \multirow{3}{*}{$\begin{array}{l}\text { Stress } \\
\text { management }\end{array}$} & Negative Ranks & 4 & 7.50 & 30.00 & -2.21 & $0.027 *$ \\
\hline & Positive Ranks & 13 & 9.46 & 123.00 & & \\
\hline & Ties & 3 & & & & \\
\hline \multirow{3}{*}{$\begin{array}{l}\text { Total } \\
\text { HLSBS-II }\end{array}$} & Negative Ranks & 4 & 4.88 & 19.50 & -3.04 & $0.002 * *$ \\
\hline & Positive Ranks & 15 & 11.37 & 170.50 & & \\
\hline & Ties & 1 & & & & \\
\hline
\end{tabular}

As it can be seen from Table 6; there is a significant difference between all other subscales except for the interpersonal relations subscale $(\mathrm{p}>.05)$ before and after interdisciplinary nutrition education course was introduced. Considering which subscales and which direction the difference is;

- After interdisciplinary nutrition education course was introduced, it was found that there is an increase in favor of the post-test in the health responsibility subscale scores of the teacher candidates $(\mathrm{Z}=-3.29 ; \mathrm{p}=.001)$. The pre-service teachers' perceptions of health responsibility (Mean Rank Pre-test $=9.81$ ) increased after the interdisciplinary nutrition education course was introduced (Mean Rank Post-test $=13.50$ ).

- After interdisciplinary nutrition education course was introduced, it was found that there is an increase in favor of the post-test in the physical activity subscale scores of the teacher candidates $(\mathrm{Z}=-2.82 ; \mathrm{p}=.005)$. The pre-service teachers' perceptions of physical activity (Mean Rank Pre-test $=5.25$ ) increased after the interdisciplinary nutrition education course was introduced (Mean Rank Post-test $=8.42$ ).

- After interdisciplinary nutrition education course was introduced, it was found that there is an increase in favor of the post-test in the nutritional habits subscale scores of the teacher candidates $(\mathrm{Z}=-2.31 ; \mathrm{p}=.021)$. The pre-service teachers' perceptions of nutritional habits (Mean Rank Pre-test $=9.80$ ) increased after the interdisciplinary nutrition education course was introduced (Mean Rank Post-test $_{1}=13.67$ ).

- After interdisciplinary nutrition education course was introduced, it was found that there is an increase in favor of the post-test in the spiritual growth subscale scores of the teacher candidates $(Z=-2.03 ; p=.048)$. The pre-service teachers' perceptions of spiritual growth (Mean Rank Pre-test $=8.33$ ) increased after the interdisciplinary nutrition education course was introduced (Mean Rank Post-test $=10.77$ ). 
- After interdisciplinary nutrition education course was introduced, it was found that there is an increase in favor of the post-test in the stress management subscale scores of the teacher candidates $(Z=-2.21 ; p=.027)$. The pre-service teachers' perceptions of stress management (Mean Rank Pre-test $=7.50$ ) increased after the interdisciplinary nutrition education course was introduced (Mean Rank Post-test $=9.46$ ).

- Finally, after interdisciplinary nutrition education course was introduced, it was found that there is an increase in favor of the post-test in the overall scale scores of the teacher candidates $(Z=-3.04 ; p=.002)$. The pre-service teachers' perceptions of healthy life style behavior levels (Mean Rank Pre-test $=4.88$ ) increased after the interdisciplinary nutrition education course was introduced (Mean Rank Post-est $_{11.37)}$.

When the results are evaluated together, it can be seen that healthy life style behavior levels of the pre-service science teachers in the experimental group (except for the subscale of interpersonal relation) increased significantly in favor of post-test scores after interdisciplinary nutrition education course was introduced.

\section{Discussion}

In this study, it is aimed to investigate the effect of interdisciplinary nutrition education on healthy life style behaviors of pre-service science teachers.

In the literature, many of the studies (Arslan \& Ceviz, 2007; Yalçınkaya, Özer \& Karamanoğlu, 2007; Tokuç \& Berberoğlu, 2007; Ertop, Y1lmaz \& Erdem, 2012; Kostak, Kurt, Süt, Akarsu \& Ergül, 2014; Ararat \& Karagün, 2016; Tedik \& Hacıalioğlu, 2017; Mete, Nacar, Tekin \& Pehlivan, 2017; Koçak, Öncel, Zincir \& Seviğ, 2017; Özkan, 2018; Toktaş, Erman \& Yetik, 2018; Karaaslan \& Çelebioğlu, 2018; Ardıç \& Taşkın, 2018) which used the Healthy Life Style Behavior Scale II (HLSBS-II) are descriptive. Together with the statistical data obtained from these studies, positive contribution was made to the literature on behalf of sub-scales of the HLSBS-II. For most of these studies, sample consisted of students from medical education; however, the sample of this study was composed with pre-service science teachers. In this study, experimental research model was used as a research method, and nutrition education was introduced with interdisciplinary approach in order to develop healthy life style behaviors.

According to the results obtained from the study, it is determined that there is a significant difference between scores from all subscales except the interpersonal relations subscale of the pre-service teachers in the experimental group before and after interdisciplinary nutrition education course was introduced. With this result, it can be said that the nutrition education leads to a positive change not only in nutrition subscale but also in other subscales. This result of the research is paralleled with a study by Abbott, Davison, Moore and Rubinstein (2012) which was carried out to examine the Aboriginal Australians with or at risk of diabetes develop recommendations for increasing the uptake and effectiveness of nutrition education in Aboriginal communities as they attend urban community cooking course. As a result of this informal nutrition education, the participants stated that they developed new skills and behaviors to support a healthy life like weight loss, increasing physical activity and smoking cessation. As a result of the present study, it was determined that the participants developed nutritional habits and health responsibilities after interdisciplinary nutrition education was introduced. This result is supported by the results of a similar study conducted by Shahril, Wan Dali and Lua (2013), it has been given 10-week multimodal nutrition education to university students and it is stated that this education brings students knowledge, attitudes and skills about nutrition. It has been observed that the experimental group students have significantly improved their dietary intake compared to the control group by increasing their energy intake, carbohydrate, calcium, vitamin C and thiamine, fruits and $100 \%$ fruit juice, fish, egg, milk and dairy products while at the same time, processed food consumption decreased significantly.

In the study, a significant difference is found between experimental and control group prospective teachers' levels of overall healthy life style behaviors. In accordance with this result, it can be said that interdisciplinary nutrition education applied to the pre-service teachers in the experimental group has a positive effect on theirs healthy life style behaviors. Although healthy life style behaviors need to be introduced to the individual at a young age, it is supported by various researches that individuals in the university period can also develop these behaviors. In a study conducted by Yıldırım, Aydın, Hayırsever and Ankaralı (2016), it was concluded that the health promotion course had a positive effect on the health promotion behaviors of nursing students. In Altun's (2008) research, it was determined that the students' healthy life style behavior average scores increased significantly as a result of health promotion course introduced to civil engineering students from Kocaeli University.

The results of the study reveal the significance of interdisciplinary nutrition education in terms of developing healthy life style behaviors. Nutritional education, which is currently applied in the undergraduate program of science education, should be included in all of the undergraduate programs, especially in the faculty of education. Furthermore, although the results of this study supported the idea that students at university level could develop healthy life style behaviors, interdisciplinary nutrition education should start from pre-school and be included in every stage of the education process. Merdol (2008) explained this situation by stating that nutrition education should be given to different age groups with 
methods that appeal to them. Nutrition education will be given to each individual member of different groups to take on the task. This is an important element in determining the training to be given to them. A study was conducted by Ünver and Ünüsan (2005) in order to determine the effect of nutritional education on nutritional knowledge level and behaviors of children in the age group of five to six $(\mathrm{N}=50)$. Nutritional education was applied to the experimental group by using various materials. The difference between scores of the participants in the experimental and the control groups after nutrition training, was significant. In a similar study performed by Geçkil and Yıldız (2006), an increase was observed in the total score of the HLSBS-II scale in the adolescents $(\mathrm{N}=122)$ who received nutrition education $(\mathrm{t}=-4.33 ; \mathrm{p}<0.001)$. In this study, in addition to nutrition education, it is aimed that students in the 14-16 age group will be given the education to cope with stress and to contribute to the health improvement of students about stress management which is a subscale of the HLSBS-II scale. However, there was no significant difference in stress management subscale total score after education while for the present study significant difference in stress management is found.

In the present study, according to other studies using the HLSBS-II scale, the total score of the HLSBS-II scale was higher; Gözüm and Tezel (2000) average M=117.6 (SD=17.3), Sertçelik (1999) M=116.08 (SD=17.92), and Yetkin and Uzun (2000) students in the mathematics department average $\mathrm{M}=116.62$ ( $\mathrm{SD}=15.22$ ), Yetkin and Uzun (2000) nursing students from the senior grade points average $\mathrm{M}=128.88$ ( $\mathrm{SD}=18.35$ ), and Özbasaran, Çetinkaya and Güngör's (2004) Health School students found their average score of $\mathrm{M}=121.92$ ( $\mathrm{SD}=1.10$ ) was calculated. However, the total mean score was calculated as $\mathrm{M}=136,00(\mathrm{SD}=22,85)$ in the pre-test and $\mathrm{M}=148,15(\mathrm{SD}=23,67)$ in the post-test.

Various researches support the results of the current study in which an interdisciplinary approach is used instead of the traditional disciplinary approach in nutrition education. It is thought that the education of nutrition with different approaches which may be more effective instead of traditional approach will increase the efficiency of educational process. Moss, Smith, Null, Long Roth, and Tragoudas (2013) conduct a study which was a quasi-experimental design analyzing the effects of the Coordinated Approach to Child Health (CATCH) nutrition curriculum with a Farm to School program to assess nutrition knowledge of $3^{\text {rd }}$ grade students $(n=65)$, and to increase fruit and vegetable consumption behavior. The CATCH nutrition curriculum is a coordinated school health program that focuses on improving the health of elementary school-aged children. CATCH emphasizes topics such as nutrition and physical activity to promote a healthy life style. In order to implement $\mathrm{CATCH}$, a nutrition education curriculum and educational activities with physical activity are developed and introduced. It is stated that implementation of $\mathrm{CATCH}$ curriculum can reduce the risk of overweight in children. Knowledge of the participating students about vitamins and minerals increased significantly in the intervention process. This result was interpreted by the researchers as a result of the presentation of the subject in a creative way. Nutrition education in this study was applied differently from the traditional teaching approach and there was an improvement in the knowledge and awareness of the students due to this difference. In another study, Mertoğlu (2018) conducted a research to determine the opinions of prospective science teachers about the nutrition-health education course which was introduced with authentic learning approach. In this context, the qualitative study group consisted of 54 senior year prospective science teachers (50 girls, 4 boys) who voluntarily took the elective nutrition-health education course. In the research, the nutrition-health course, which was introduced with an authentic learning approach, was applied to the participant science teacher candidates. As a result of the study, it was found that all of the prospective teachers stated that taking the nutrition-health education course with authentic learning approach positively contributed to the course and students' healthy eating behaviors and habits. At the same time, the prospective teachers stated that after taking the course they become more capable of relating the topics learned in theory to daily life and they had a better understanding of society's perspective on nutrition and health.

Teacher candidates undertake an important social role. One of the mechanisms that play a critical role in the transmission of social problems to future generations is schools. Schools are structures where students include society and they gain vital experiences, as well. As stated by Shulman and Shulman (2004), if the relationship between teachers and students is strong, students are positively affected by their teachers in many aspects of personal development. It is an undeniable fact that teachers and peers have an impact on the students as well as the effect of the families. Schools have large share about gaining nutrition behavior of future generations. In this point, prospective teachers receive nutrition education by comprehending their incumbent social role. Through interdisciplinary nutrition education, teachers will contribute to healthy life style behaviors of future generations while contributing to their healthy life style behaviors.

In this study, it was concluded that interdisciplinary nutrition education has positive effects on students' healthy life style behaviors. In other words, interdisciplinary nutrition education has contributed to the development of healthy life style behaviors. 
According to the results of the research, some suggestions were made:

1. Nutrition education course given as elective course in the undergraduate science education program of the Faculty of Education should transform into compulsory course and included in the teaching programs of all other branches.

2. Nutrition education should be handled with an interdisciplinary approach, not through a theoretical course that is formed by a disciplinary approach.

3. Since habit and behavior development could be easier at a young age, nutrition education should be provided throughout the entire education period, starting with pre-school education.

This study has some limitations. These can be listed;

- Each individual has developmental differences like self-knowledge and control skills, interest area and also environment. Such differences can multifariously affect the result of the study.

- Although the experimental and control groups found as equilevent groups for the study, it can be accepted as limitation for the study that participant numbers of control group and experimental group are not equivalent while both of them needs to be in close numbers to each other.

- Also, the study is restricted with given participant numbers from one public university in Turkiye, İstanbul.

The literature has limited materials in terms of interdisciplinary nutrition education. Therefore, in line with the results of this study, a number of recommendations were made for further researches:

1. In the current study, there was no significant difference between the pre-test and post-test scores of prospective science teachers' healthy life style behaviors at subscale of interpersonal relationships. Therefore, the content of interdisciplinary nutrition education should be reviewed and should be prepared as for improving interpersonal relationship behaviors.

2. It is recommended that the education curricula should be structured to ensure the active participation of the students

\section{References}

Abbott, P. A., Davison, J. E., Moore, L. F., \& Rubinstein, R. (2012). Effective nutrition education for Aboriginal Australians: lessons from a diabetes cooking course. Journal of nutrition education and behavior, 44(1), 55-59. https://doi.org/10.1016/j.jneb.2010.10.006

Ak, Ş., Çelen, Ü., Özen, Y., Tabak, R. S., \& Piyal, B. (2006). Ankara merkez ilçeler ilköğretim okulları çalışanlarının sağlık davranışları. TSK Koruyucu Hekimlik Bülteni, 5(2), 83-93.

Al Ma'aitah, R., Haddad, L., \& Umlauf, M. G. (1999). Health promotion behaviors of Jordanian women. Health Care for Women International, 20(6), 533-546. https://doi.org/10.1080/073993399245449

Altun, I. (2008). Effect of a health promotion course on health promoting behaviours of university students. Eastern Mediterranean Health Journal, 14(4), 880-887.

Ararat, Y., \& Karagün, E. (2016). Beden eğitimi ve spor öğretmen adaylarının sağlık davranışlarının incelenmesi. Kocaeli Üniversitesi Sağllk Bilimleri Dergisi, 2(1), 23-27. https://doi.org/10.30934/kusbed.358487

Ardıç, C., \& Taşkın, N. (2018). An Evaluation of Healthy Lifestyle Behaviors of Medical School Students. Bezmialem Science, 6(3), 191-195. https://doi.org/10.14235/bs.2018.1856

Arslan, C., \& Ceviz, D. (2007). Ev hanımı ve çalışan kadınların obezite prevalansı ve sağlıklı yaşam biçimi davranışlarının değerlendirilmesi. Firat Üniversitesi Sağllk Bilimleri Dergisi, 21(5), 211-220.

Arslan, P., \& Pekcan, G. (1985). Yurtta kalan yüksek öğrenim gençlerinin beslenme durumları ve sorunları diabet yıllığı. 4. Temel Matbaası Cerrahpaşa Tıp Fakültesi İstanbul Üniversitesi XIX. Diabet Günleri Gençlik ve Beslenme Kongresi, İstanbul.

Bahar, Z., Beşer, A., Gördes, N., Ersin, F., \& Kıssal, A. (2008). Sağlıklı yaşam biçimi davranışları ölçeği II'nin geçerlik ve güvenirlik çalışması. Cumhuriyet Üniversitesi Hemşirelik Yüksekokulu Dergisi, 12(1), 1-13.

Baumslag, N., Gatins, K., Watson, D. R., \& Englund, A. (1976). Interdisciplinary nutrition education. Academic Medicine, 5l(1), 64-66. https://doi.org/10.1097/00001888-197601000-00014

Bidlack, W. R. (1996). Interrelationships of food, nutrition, diet and health: The National Association of State Universities and Land Grant Colleges White Paper. Journal of the American College of Nutrition, 15(5), 422-433. https://doi.org/10.1080/07315724.1996.10718620 
Büyüköztürk, Ş., Kılıç Çakmak, E., Akgün, Ö. E., Karadeniz, Ş., \& Demirel, F. (2013). Bilimsel araştırma yöntemleri. Ankara: Pegem Akademi.

Carreno, J., Vyhmeister, G., Grau, L., \& Ivanovic, D. (2006). A health promotion programme in Adventist and non-Adventist women based on Pender's model: A pilot study. Public health, 120(4), 346-355. https://doi.org/10.1016/j.puhe.2005.08.023

Engle, P. L., Castle, S., \& Menon, P. (1996). Child development: Vulnerability and resilience. Social science \& medicine, 43(5), 621-635. https://doi.org/10.1016/0277-9536(96)00110-4

Ertop, N. G., Yılmaz, A., \& Erdem, Y. (2012). Üniversite öğrencilerinin sağlıklı yaşam biçimleri. Kırıkkale Üniversitesi Tip Fakültesi Dergisi, 14(2), 1-7.

Geçkil, E., \& Yıldız, S. (2006). Adölesanlara yönelik beslenme ve stresle başetme eğitiminin sağlığı geliştirmeye etkisi. Cumhuriyet Üniversitesi Hemşirelik Yüksek Okulu Dergisi, 10(2), 19-28.

Gözüm, S., \& Tezel, A. (2000). Yurtta kalan üniversite öğrencilerinin sağlık davranışlarını etkileyen faktörlerin path analiziyle açıklanması. I. Uluslar Arası ve VIII. Ulusal Hemşirelik Kongresi. Kongre Kitabı. Antalya, 29, 294-300.

Heath, G. W., Pratt, M., Warren, C. W., \& Kann, L. (1994). Physical activity patterns in American high school students: results from the 1990 Youth Risk Behavior Survey. Archives of pediatrics \& adolescent medicine, 148(11), 1131-1136. https://doi.org/10.1001/archpedi.1994.02170110017003

Jacobs, H. (1989). Interdisciplinary curriculum: Design and implementation. Alexandria, VA: Association for Supervision and Curriculum Development.

Kalaycı, Ş. (2006). SPSS Uygulamalı Çok Değişkenli İstatistik Teknikleri. 2’nci Baskı, Ankara: Asil Yayın Dağıtım.

Karaaslan, M. M., \& Çelebioğlu, A. (2018). Determination of healthy lifestyle behaviors of high school students. Journal of Human Sciences, 15(2), 1355-1361. https://doi.org/10.14687/jhs.v15i2.4895

Koçak, H. S., Öncel, S., Zincir, H., \& Seviğ, E. Ü. (2017). Sınıf öğretmenlerinde tip 2 diyabet riski ve sağlıklı yaşam biçimi davranışlarının belirlenmesi. Turkish Journal of Public Health, 15(2), 70-83.

Kocatepe, D., \& Tir1l, A. (2015). Healthy nutrition and traditional foods. Journal of Tourism and Gastronomy Studies, $3(1), 55-63$.

Kostak, M. A., Kurt, S., Süt, N., Akarsu, Ö., \& Ergül, G. D. (2014). Hemşirelik ve sınıf öğretmenliği öğrencilerinin sağlıklı yaşam biçimi davranışları. TAF Preventive Medicine Bulletin, 13(3), 189-196. https://doi.org/10.5455/pmb.1-1362174271

Merdol, T. (2008). Beslenme Eğitimi ve Danışmanlığı. Ankara: Klasmat Matbaacılık.

Mertoğlu, H. (2018). Otantik beslenme-sağlık eğitimi dersi ve öğretmen adaylarının görüşleri, Jass Studies-The Journal of Academic Social Science Studies, 72, 85-102. https://doi.org/10.9761/JASSS7835

Mete, B., Nacar, E., Tekin, Ç., \& Pehlivan, E. (2017). Tıp fakültesi öğrencilerinde beslenme ve sağlıklı yaşam biçimi davranışları. Uluslararası Hakemli Beslenme Araştırmaları Dergisi, 9, 16-30.

Moss, A., Smith, S., Null, D., Long Roth, S., \& Tragoudas, U. (2013). Farm to school and nutrition education: Positively affecting elementary school-aged children's nutrition knowledge and consumption behavior. Childhood Obesity, 9(1), 51-56. https://doi.org/10.1089/chi.2012.0056

Özbaşaran, F., Çetinkaya, A. Ç., \& Güngör, N. (2004). Celal bayar üniversitesi sağlık yüksekokulu öğrencilerinin sağlık davranışları. Atatürk Üniversitesi Hemşirelik Yüksekokulu Dergisi, 7(3), 43-55.

Özkan, A. (2018). Stnıf öğretmenlerinin ve adaylarının enerji ve besin öğesi alımları (beslenme alışkanlıkları) ile sağllklı yaşam biçimi davranışlarının ve fiziksel aktivite düzeylerinin belirlenmesi (master's thesis). Bartın University Institute of Education Sciences, Bartın.

Özyazıcıoğlu, N., Kılıç, M., Erdem, N., Yavuz, C., \& Afacan, S. (2011). Hemşirelik öğrencilerinin sağlıklı yaşam biçimi davranışlarının belirlenmesi. Uluslararası İnsan Bilimleri Dergisi, 8(2), 277-332.

Sertçelik, E. (1999). Üniversiteli gençlerin sağlık davranışlarının belirlenmesi (master's thesis). Istanbul University Institute of Health Sciences, Istanbul.

Shahril, M. R., Wan Dali, W. P. E., \& Lin Lua, P. (2013). A 10-week multimodal nutrition education intervention improves dietary intake among university students: Cluster randomised controlled trial. Journal of Nutrition and Metabolism, 2013, 1-11. https://doi.org/10.1155/2013/658642

Shulman, L. S., \& Shulman, J. H. (2004). How and what teachers learn: A shifting perspective. Journal of curriculum 
studies, 36(2), 257-271. https://doi.org/10.1080/0022027032000148298

Sinir, G. Ö., İncedayı, B., Çopur, Ö. U., Kaplan, E., \& Bekaroğlu, M. (2014). Uludağ üniversitesi'nde eğitim gören öğrencilerin beslenme alışkanlıklarının araştırılması. Uludağ Üniversitesi Ziraat Fakültesi Dergisi, 28(2), 37-47.

Sönmez, V., \& Alacapınar, F. G. (2016). Sosyal bilimlerde ölçme aracı hazırlama. Ankara: Anı Yayıncılık.

Tedik, E., \& Hacıalioğlu, N. (2017). Hemşirelik öğrencilerinde fazla kilo durumu ve sağlıklı yaşam biçimi davranışları arasındaki ilişkinin incelenmesi. Uluslararası Hakemli Hemşirelik Araş̧ırmaları Dergisi, 10, 59-82. https://doi.org/10.17371/UHD2017.2.04

Toktaş, N., Erman, K. A., \& Yetik, O. (2018). Erkek üniversite öğrencilerinin kronotipe göre sağlıklı yaşam biçimi davranışları ve fiziksel aktivite düzeyleri. Abant İzzet Baysal Üniversitesi Eğitim Fakültesi Dergisi, 18 (1), 507-520. https://doi.org/10.17240/aibuefd.2018.18.36350-411092

Tokuç, B., \& Berberoğlu, U. (2007). Edirne merkez ilçe ilköğretim okullarında çalışan öğretmenlerde sağlığı geliştirici davranışlar. Tsk Koruyucu Hekimlik Bülteni, 6(6), 421-426.

Ünver, Y., \& Ünüsan, N. (2005). Okulöncesinde beslenme eğitimi üzerine bir araştırma. Selçuk Üniversitesi Sosyal Bilimler Enstitüsü Dergisi, 14, 529-551.

Walker, S. N., Sechrist, K. R., \& Pender, N. J. (1987). The Health-Promoting Lifestyle Profile: Development and psychometric characteristics. Nursing Research, 36, 76-80. https://doi.org/10.1097/00006199-198703000-00002

World Health Organization. (1995). Constitution of the world health organization.

Yalçınkaya, M., Özer, F. G., \& Karamanoğlu, A. Y. (2007). Sağlık çalışanlarında sağlıklı yaşam biçimi davranışlarının değerlendirilmesi. Tsk Koruyucu Hekimlik Bülteni, 6(6), 409-420.

Yardım, N., Gögen, S., \& Mollahaliloğlu, S. (2009). Sağlığın geliştirilmesi (Health Promotion): Dünyada ve Türkiye'de mevcut durum. İstanbul Tip Fakültesi Dergisi, 72(1), 29-35.

Yetkin, A., \& Uzun, Ö. (2000). Eğitimi sağlıkla ilgili olan ve olmayan yüksekokul öğrencilerinin sağlık davranışlarının karşılaştırılması. Anadolu Hemşirelik ve Sağllk Bilimleri Dergisi, 3(2). Retrieved from https://dergipark.org.tr/tr/pub/ataunihem/issue/2618/33697

Yıldırım, A. (1996). Disiplinlerarası Öğretim Kavramı ve Programlar Açısından Doğurduğu Sonuçlar. Hacettepe Üniveristesi Eğitim Fakültesi Dergisi, 12, 89-94.

Yıldırım, N., Aydın, M., Hayırsever, F., \& Ankaralı, H. (2016). Bir hemşirelik lisans programında verilen sağlı̆̆ geliştirme dersinin etkinliği. Dokuz Eylül Üniversitesi Hemşirelik Fakültesi Elektronik Dergisi, 9(3), 88-92.

\section{Copyrights}

Copyright for this article is retained by the author(s), with first publication rights granted to the journal.

This is an open-access article distributed under the terms and conditions of the Creative Commons Attribution license which permits unrestricted use, distribution, and reproduction in any medium, provided the original work is properly cited. 